\title{
Family Characteristics That Suffer Stunting in the Work Area of The District Health Center Langkat
}

\author{
Siti Saidah Nasution', Bina Melvia Girsang ${ }^{2}$ \\ Departement of Maternity, Faculty of Nursing, Universitas Sumatera Utara
}

\begin{abstract}
Stunting is malnutrition a long time and have an adverse impact on health status, growth and development of children. Signs and symptoms of stunting is child's posture is short i.e. the height is not appropriate with age. Malnutrition in children is related to the characteristics of the family as a place of growing and the care of the child. This research is descriptive quantitative research with the aim to analyze the characteristics of families with children who suffer from stunting. The study population 136 as much as with the total sample of 30 mothers who have children and toddlers with simple random sampling. Data collection using a questionnaire, consisting of demographic data, the role of family function and health status associated with stunting. Data analysis univariate. The results of the research showed that the. The importance of assessing the characteristics of the family in the treatment in children and infants.
\end{abstract}

Keyword: Stunting, Characteristics, Family

Received 18 December 2019| Revised 29 December 2019 | Accepted 29 December 2019

\section{Introduction}

Babies and toddlers are the age that are prone to experiencing problems of nutrition, if at this age the growth and development of children does not occur optimally it will be a source of qualified human resources (DepKes, RI, 2012). The intake of nutritional substances is important, for the body to perform functions such as producing energy, build and maintain the network. Provision of appropriate food for children can reduce the problems of nutrition, where children who consume food variety have a good level of health. Eat variegated to meet the nutritional needs because none of the types of food which have the content of nutrition complete. Eating a wide variety will increase the level of nutrient intake and reduce stunting in infants and toddlers (Almatsier, 2010)

Stunting is the problem of chronically undernourished e of intake nutrition that is lacking in quite a long time due to administration food that is not in accordance with nutritional needs.

*Corresponding author at: Jl. Prof.Maas No. 03 Kampus USU, Medan, Indonesia.

E-mail address: siti.saidah@usu.ac.id 
Currently, Indonesia is one of the 117 Countries in the World that has the issue of nutrition high on the toddlers, namely stunting, wasting, and overweight reported in the Global Nutrition Report (GNR) 2014 Nutrition Country Profile Indonesia. Of the three such problems, Stunting is a problem that is biggest that with the incidence of up to $37,2 \%$ (Millennium Challenga Account Indonesia. 2014, IIFPRI (2014) Health Research Data (Riskesdas) in the year 2018 shows the prevalence of toddler short (Stunting) nationally in Indonesia reached 30,2\%. The results of the survey monitoring nutritional status (PSG) in 2015 in North Sumatra is about to $34.9 \%$ and $16.5 \%$ of infants under 5 years old (toddlers) have grown very short. Wrong or regions with the incidence of stunting is high disumatera north one is Langkat district with the prevalence of stunting reached (55,48\%) (Buku Saku: Pemantauan Status G, 2017). Stunting (short stature) is an indication of the lack of nutritional intake, both in quantity and in quality which is not met since the baby, even in the womb. This condition causes the child to have a high body tend to be short on her age (Buku Saku Desa dalam Penanganan Stunting, 2017). In addition to the short body, the stunting also poses another impact on children, both short-term impact and long-term impact. The short-term impact, namely in childhood, the development be hampered, the decline of cognitive function decline immune, infants are far more often exposed to diseases than children in general (Kementrian DPDTT.2017 \& Millennium Challenga Account Indonesia. 2014). The long-term impact on the adult, child stunting affect the mindset of the child and the risk of place the of degenerative diseases, such as Diabetes Mellitus, coronary heart disease, hypertension, and Obesity (Stright, 2005). One of the factors that influence health status, including the fulfillment of family nutrition is the role of family functions (Nasution,2018). The family is the environment of the first known people so that the family is the determinant of the basis of the formation of the character of a person. The relationship between family members is a relationship that very closely as well as has a very high intensity on each member of the family (Ibrahim, 2014 \& Notoatmodjo, 2003).

The family has a very important role in the growth and development of the child, because in the family environment, the child will get the needs of the needs required by the children, ranging from physical needs such as food, clothing and shelter to spiritual needs such as guidance, education, and affection of the parents. Since the human still in the womb until born, the child already feel the love and affection of her parents (Notoatmodjo, 2003).

Basicly, the survival and health of infants and toddlers can not be separated from the role of family function. Family should be the castle in the meet the needs of the child first. The role of the function of the family is necessary to children's growth, namely with the provision of the intake of enough nutrition and feeding behavior appropriate (Friedman, 1998). 


\section{Methods}

This research is a quantitative research which aims to determine the characteristics of the family suffering from stunting Population in this study were all infants and toddlers in the region. The number of samples 30 people. Intervention is health education about sexual behavior in adolescents related to physical and psychological care. Research conducted in April until October 2019. The questionnaire was divided into 3 parts consisting of the characteristic.

\section{Result}

\subsection{Characteristics of respondents}

Respondent Characteristic of Age of Mother, Number of Child, Mother Graduated, Father's Job, Mother's Job, Income According Minimum Wage, Religion, Mother's Knowledge about Stunting, Ban on eating.

Table 1. Distribution of Respondent Characteristic $(\mathrm{n}=136)$

\begin{tabular}{|c|c|c|}
\hline Variable & $\mathrm{N}(30)$ & $\%$ \\
\hline \multicolumn{3}{|l|}{ Age of Mother } \\
\hline Risk Age & 25 & 83.3 \\
\hline Productive Age & 5 & 16.7 \\
\hline \multicolumn{3}{|l|}{ Number of Child } \\
\hline Primi & 8 & 26.7 \\
\hline 1-2 Children & 10 & 33.3 \\
\hline$>2$ Children & 12 & 40 \\
\hline \multicolumn{3}{|l|}{ Mother Graduated } \\
\hline Elementary School & 18 & 60 \\
\hline Junior High School & 6 & 20 \\
\hline Senior High School & 4 & 13.3 \\
\hline Diploma/ Bachelor & 2 & 6.7 \\
\hline \multicolumn{3}{|l|}{ Father's Job } \\
\hline Enterpreneur & 4 & 13.3 \\
\hline Civil Servant & 2 & 6.7 \\
\hline Farmer & 10 & 33.3 \\
\hline Fisherman & 14 & 46.7 \\
\hline \multicolumn{3}{|l|}{ Mother's Job } \\
\hline Housewife & 9 & 30 \\
\hline Enterpreneur & 7 & 23.3 \\
\hline Civil Servant & 2 & 6.7 \\
\hline Farmer & 6 & 20 \\
\hline Fisherman & 6 & 20 \\
\hline \multicolumn{3}{|c|}{ Income According Minimum Wage } \\
\hline Yes & 25 & 83.3 \\
\hline No & 5 & 16.7 \\
\hline \multicolumn{3}{|l|}{ Religion } \\
\hline Moslem & 26 & 86.7 \\
\hline Christian & 4 & 13.3 \\
\hline \multicolumn{3}{|c|}{ Mother's Knowledge about Stunting } \\
\hline Good & 8 & 26.7 \\
\hline Worst & 22 & 73.3 \\
\hline \multicolumn{3}{|l|}{ Ban on eating } \\
\hline Yes & 23 & 76.7 \\
\hline No & 7 & 23.3 \\
\hline
\end{tabular}


Based on Table 1 showed that mother graduated were Elementary School 60\%, Mother's Knowledge about Stunting were worst $73.3 \%$, there is ban on eating $76.7 \%$

Table 2. Distribution of Health Status ( $n=136)$

\begin{tabular}{lcc}
\hline \multicolumn{1}{c}{ Health Status } & $\mathrm{n}$ & $\%$ \\
\hline Stunting & 30 & 22.1 \\
No Stunting & 106 & 77.9 \\
\hline
\end{tabular}

Based on Table 2 showed that health status of children were stunting $22.1 \%$ and no stunting $77.9 \%$

\section{Discussion}

The family is the most instrumental in the care of the child. Family especially the parents are responsible to meet the food and adequacy of nutrition elements (Ibrahim, 2014). Based on the results of this study there are data characteristics of families with children who have the incidence of stunting. Family is the people closest that can give you motivation on the mother in making decisions in the care of the family include providing the child's food (Ibrahim, 2014). It is supported by the concept of a declared health education is not the only factor that affects a person's behavior but is influenced by factors external support that can directly affect changes in behavior as a means of owned, other facilities available or the tools needed as well as the positive support given to others to occur a change in behavior means that the respondents have a good knowledge not necessarily have good behavior and vice versa (Notoatmodjo, 2003). Role and functions. The behavior of the mother in feeding or feed, how to eat healthy, providing nutritious foods and control a large portion of that is spent will improve the nutritional status of children (Nasution, 2018 \& Ramayana 2014). In this research, there are habits in the family, namely the presence of abstinence in a society that is based on customs and customs and local habits, as children are not fed eggs and fish by reason of the child of intestinal worms if you eat that fishy. Feeding in infants and children is an important foundation in the growth process. Worldwide about $30 \%$ of children under five years experiencing stunted is a consequence of the practice of giving poor feeding and repeated infections (Aridiyana, 2015). Required the creativity of the mother in preparing a draft menu that is best for the child. Such creativity can be supported with the knowledge of the mother.

Knowledge is the result of know and occurs after the person doing the sensing on a particular object. Sensing occurs through human senses, namely sight, hearing, smell, taste, and conjecture. Knowledge can be obtained among others, through education both curricular, non curricular and extracurricular activities. Knowledge also can be obtained from the knowledge of others, such as: hearing, seeing directly and through communication tools such as television, radio, books and others (Wijogowati, 2010). Knowledge can improve control of emotions, increasing self-reliance of clients, increases self-esteem, increase endurance as well as can help 
the client to adapt to the problem or the disease that ultimately can improve health status (Notoatmojo, 2012 \& Nasution, 2015).

In this study the mothers have poor knowledge about stunting. It is also shown with tinggat education of the mother secondary school first which is in the category of level s low. Knowledge is very closely connected with education, where it can be assumed that with a high education then the person will be also the more extensive his knowledge. Low education does not guarantee a mother does not have sufficient knowledge about the nutrition of his family. The absence of curiosity that can affect the mother in getting the information about the right food to the child (Silas, 2018). The level of education of the mother will affect the health and welfare of the child so that this will affect the nutritional status of children (Olsa, 2017).

Mothers with high levels of education will more easily absorb the information when compared with mothers who are less or not educated, so with a considerable level of education expected of a mother willing and able to behave better in order to improve the nutritional status of her child. This is supported by research conducted by (Sulastri, 2012). That mothers with low education levels have the opportunities their children experience stunting by 0,049 times greater compared with mothers who have higher education. effect on the probability of stunting.

\section{Conclusion}

1. Family characteristics play a role in the occurrence of stunting in children

2. Need to study the characteristics of families in carrying out health programs related to stunting.

\section{Advice}

1. Health officer through the health center should conduct health education in particular about the stunting on the public on a continuous basis.

2. Health workers prepare a variety of media, leaflets and a guide for families, especially parents how to detect and prevent the occurrence of stunting in children.

\section{Acknowledgment}

Thanks to the research institute USU which has helped funding the research through the TALENT program. Thanks to different and government of Langkat district, especially the fateral Public Health Center Secanggang and the surrounding community. 


\section{REFERENCES}

[1] Departemen Kesehatan Republik Indonesia.Pedoman gizi seimbang. Jakarta: Depkes RI; 2012.

[2] Almatsier,H, 2010,Prinsip Dasar Ilmu Gizi. Jakarta: PT. Gramedia Pustaka Utama.

[3] Buku Saku: Pemantauan Status Gizi (2017). Hasil Pemantauan Status Gizi (PSG): Kementerian Kesehatan Republik Indonesia.

[4] Millennium Challenga Account Indonesia. 2014. Stunting dan Masa Depan Indonesiainfo@mca-indonesia.go.id|www.mca-indonesia.go.id.

[5] IFPRI (2014) Global Nutrition Report 2014: Action and Accountability to Accelerate the World's Progress on Nutrition. International Food Policy Research Institute.Washington DC.

[6] Buku Saku: Pemantauan Status Gizi (2017). Hasil Pemantauan Status Gizi (PSG): Kementerian Kesehatan Republik Indonesia.

[7] Buku Saku Desa dalam Penanganan Stunting (2017). Kementerian Desa, Pembangunan Daerah Tertinggal dan Transmigrasi.

[8] Kementrian DPDTT.2017. Buku Saku Desa dalam Penanganan Stunting.Kementrian DPDTT

[9] Millennium Challenga Account Indonesia. 2014. Stunting dan Masa Depan Indonesiainfo@mca-indonesia.go.id|www.mca-indonesia.go.id.

[10] Stright, Barbara. (2005).Keperawatan Ibu-Bayi Baru Lahir, Edisi 3., Jakarta: EGC.

[11] Nasution. S.S, Erniyati, Ellyta Aizar (2018). The Effectiveness of DC Motor Vibrilatory Stimulus (DMV) among Postpartum Women on Giving Breast Milk. Open access Macedonia Journal of Medical science. http://wwww.idpress.eu/mjms/index

[12] Ibrahim, I A., Faramita, R. Hubungan Faktor Sosial Ekonomi Keluarga dengan Kejadian Stunting Anak Usia 24-59 Bulan di Wilayah Kerja Puskesmas Barombong Kota Makassar Tahun 2014. Al-Sihah : Public Health Science Journal. 2014; 7(1): 63-75

[13] [Notoatmodjo, S. (2003). Ilmu Kesehatan Masyarakat (Prinsip-Prinsip Dasar). Jakarta: PT. Rineka Cipta

[14] Friedman, M.M., (1998). Family Nursing Research Theory \& Practice. (4.ed). Connectieut:Appleton\&Large.

[15] Nasution. S.S. (2018). Asuhan Keperawatan pada Ibu Hamil Resiko Tinggi: HIVAIDS (dengan Melibatkan Masyarakat). Medan. USU Press

[16] Ramayana, Ibrahim, I. A., Damayati, D. S. Hubungan Pola Asuh Ibu Dengan Kejadian Stunting Anak Usia 24-59 Bulan Di Posyandu Asoka II Wilayah Pesisir Kelurahan Barombong Kecamatan Tamalate Kota Makassar Tahun 2014. Al-Sihah : Public Health Science Journal. 2014; 6(2): 424-436

[17] Aridiyana, F.O., Rohmawati, N., Ririanty, M. Faktor-faktor yang Mempengaruhi Kejadian Stunting pada Anak Balita di Wilayah Pedesaan dan Perkotaan (The Factors Affecting Stunting on Toddlers in Rural and Urban Areas). e-Jurnal Pustaka Kesehatan. 2015; 3(1): 163-170

[18] Wijogowati, Citaningrum. Kejadian Stunting Pada Anak Berumur Pada Anak Berumur Di Bawah Lima Tahun (0- 59 Bulan) Di Provinsi Papua Barat Tahun 2010. Skripsi. Depok: Program Studi Ilmu Kesehatan Masyarakat Fakultas Kesehatan Masyarakat, 2010.

[19] Notoatmojo S. Promosi kesehatan dan perilaku kesehatan. Jakarta: Rineka Cipta; 2012.

[20] Silas, L., Rantetampang, A.L., Tingginehe, R.,Mallengi, A.. The Factors Affecting Stunting Child under Five Years in Sub Province Mimika. International Journal of Science and Healthcare Research. 2018;3(2): 99-108.

[21] Olsa, E. D., Sulastri, D., Anas, E. Hubungan Sikap dan Pengetahuan Ibu Terhadap Kejadian pada Anak Baru Masuk Sekolah Dasar di Kecamanatan Nanggalo. Jurnal Kesehatan Andalas. 2017; 6(3): 523-529

[22] Sulastri D. Faktor determinan kejadian stunting pada anak usia sekolah di Kecamatan Lubuk Kilangan Kota Padang. Majalah Kedokteran Andalas. 2012;36(1):39-50 
[23] Nasution SS, Badaruddin, Dasatjipta G, Lubis Z. Effectiveness of the health awareness community team intervention in improving the maternal and neonatal health statusin mandailing natal (madina) Sumatera Utara Indonesia. International Journal of Medical Science and Public Health. 2015; 4(6):799-804. 